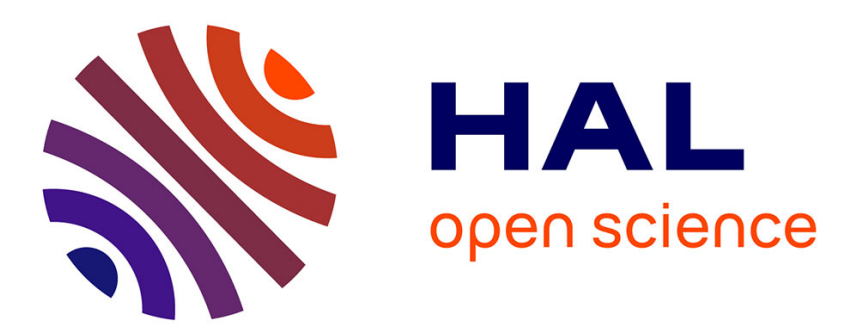

\title{
Vulnerability to forest decline in a context of climate changes: new prospects about an old question in forest ecology
}

Nathalie Bréda, Marianne Peiffer

\section{- To cite this version:}

Nathalie Bréda, Marianne Peiffer. Vulnerability to forest decline in a context of climate changes: new prospects about an old question in forest ecology. Annals of Forest Science, 2014, 71 (6), pp.627-631. 10.1007/s13595-014-0411-3 . hal-01102685

\section{HAL Id: hal-01102685 \\ https://hal.science/hal-01102685}

Submitted on 13 Jan 2015

HAL is a multi-disciplinary open access archive for the deposit and dissemination of scientific research documents, whether they are published or not. The documents may come from teaching and research institutions in France or abroad, or from public or private research centers.

$$
\text { Copyright }
$$

L'archive ouverte pluridisciplinaire HAL, est destinée au dépôt et à la diffusion de documents scientifiques de niveau recherche, publiés ou non, émanant des établissements d'enseignement et de recherche français ou étrangers, des laboratoires publics ou privés. 


\title{
Vulnerability to forest decline in a context of climate changes: new prospects about an old question in forest ecology
}

\author{
Nathalie Bréda • Marianne Peiffer
}

Received: 30 June 2014 / Accepted: 9 July 2014 / Published online: 5 August 2014

(C) INRA and Springer-Verlag France 2014

\section{Why focus on vulnerability?}

Forest research has been particularly efficient in detecting the impacts of variability and long-term trends of climate. It is indeed in these ecosystems gathering perennial plants with a long lifespan that the first visible impacts of climate change have been convincingly documented. At first, positive changes in productivity were detected (Becker 1989; Becker et al. 1994; Badeau et al. 1995; Badeau et al. 1996). Improved growth conditions linked to warming, to nitrogen deposition and to increased atmospheric $\mathrm{CO}_{2}$ were perceived fairly early and were also heterogeneous among biogeographical areas due to local limiting factors (trophic or climatic). The first thoughts about the Dryade project were initiated during 2006. In France, the first simulations of potential impacts of available climate scenarios generated awareness, criticism and concerns among managers and foresters (Carbofor, Loustau et al. 2005; Badeau et al. 2010). In addition to climate trends, extreme events had already been identified as a major cause of forest dieback. All major drought events were historically followed by cycles of dieback

\section{Handling Editor: Erwin Dreyer}

Contribution of the co-authors Nathalie Bréda was the coordinator of the ANR-06-VULN-004 and has contributed as an editor associated with this special issue devoted to research conducted during the interdisciplinary research program "DRYADE". She was particularly attentive to assist and support the publication of manuscripts of $\mathrm{PhD}$ students and young researchers supported by the project. Marianne Peiffer was involved in the management and coordination of the project; she also contributed as managing editor of Annals of Forest Sciences to publish this special issue.

N. Bréda $(\bowtie) \cdot$ M. Peiffer

INRA, UMR 1137 Ecologie et Ecophysiologie Forestières,

54280 Champenoux, France

e-mail: breda@nancy.inra.fr

N. Bréda $\cdot$ M. Peiffer

Université de Lorraine, UMR 1137 Ecologie et Ecophysiologie

Forestières, BP 239, F-54506 Vandoeuvre, France
(Innes et al. 1989; Jones et al. 1993; Landmann 1994; Beniston and Innes 1998; Thomas et al. 2002; Liang et al. 2003; Jurskis 2005). In France, forest dysfunctions induced by the drought events of 2003-2006 were mostly reversible (growth decrease, temporary degradation of crown conditions) but sometimes also irreversible (tree mortality). Several indicators of forest health surveys pointed to a degradation of forest health in France and Europe: abnormal increases in tree mortality (Pauly and Belrose 2005), decline of crown conditions (Lloret et al. 2004; Pauly and Belrose 2005; Belrose et al. 2004, 2006; Carnicer et al. 2011) and upsurge in biotic hazards (Nageleisen 2004; Piou et al. 2006; Rouault et al. 2006).

\section{Need for common language}

When the Dryade project started, the vulnerability concept was not yet fully appropriated by the research community in ecology. No measurement of the vulnerability of ecosystems to climate change was yet established. Generic concepts in ecology like the ecosystem resilience to disturbances (Holling 1986; Manion 1991, 2003; Jurskis 2005) and of concepts in geography and natural hazards (Briguglio 2004; Eriksen and Kelly 2007) have been debated. Several papers published concomitantly with the Dryade program (Bodin and Wiman 2007; Williams et al. 2008) allowed us to define the concepts underlying the research approach developed during Dryade. Vulnerability refers to the propensity or predisposition to be adversely affected by the effects of climate change, including climate variability and extreme weather events. Vulnerability encompasses a variety of concepts including sensitivity or susceptibility to harm and lack of capacity to cope and adapt (IPCC 2014). In our perspective, the IPCC's definition was applied to forest ecosystems. Vulnerability is a relative notion (Fussel 2007) that should be fully qualified according to (1) the attribute of concern (in our forest context for example, 
biodiversity, productivity, regeneration, mortality and decline) and (2) a temporal reference (past, current, future, dynamic i.e. immediate or delayed, multiannual or long term).

\section{Research methods}

Unlike what is sometimes claimed, the most vulnerable forest ecosystems are not necessarily mountain or Mediterranean forests, or forests with species at the margin of their distribution. The Dryade consortium investigated cases of forest dieback in the core of the production area in France for Douglas fir, beech or temperate oaks. Dryade mainly focussed on consequences of pulse disturbances like the 2003 heat and drought event and less on press disturbance like chronic acidification or temperature increase. Nevertheless, longterm trends were investigated with a retrospective approach using dendrochronological approaches. Parallel to Dryade (Bréda 2013), other projects focussed on modelling potential impacts on agro- and ecosystems using scenarios of future climate (CLIMATOR, ANR-06-VULN-014, QDIV, ANR-05BDIV-009-01, GICC FAST) or ecosystem manipulation to simulate drought events (DROUGHT+, ANR-06-VULN-003). Brief summaries of these projects may be found in Granier (2013), Rambal (2013), Durand (2013) and Cheaib et al. (2012). Dryade concentrated on realized and direct impacts of acute drought stress, sometimes in interaction with insect or pest disturbances. Different approaches were mobilized to disentangle, identify and rank the determinants of vulnerability. The realized impacts from a natural hazard, of a given intensity, were quantified for several forest attributes of concern. Three types of attributes were investigated: tree health, radial growth and mortality (Dobbertin 2005). The realized impacts were quantified through (i) radial growth or productivity loss in reference to norms or to trees not exposed to the hazard or (ii) crown condition visually assessed as compared to a reference tree (dead branches, foliar loss and crown transparency). The database from the French Forest Health Department (http:// agriculture.gouv.fr/suivi-de-la-sante-des-forets) was analysed to quantify and localize biotic hazards (pests and diseases) and their impact on forest decline. Growth response functions to climate and drought (quantified from soil water content derived from water balance models) were assessed for radial growth, tree ring texture or wood micro-density. Pairs of living and dead trees or healthy and declining trees were used to identify the traits describing individual vulnerability within stands and forests.

Identifying the determinants of the vulnerability of ecosystems implies to (1) identify the disturbance (climatic event, pest, disease or their interaction); (2) quantify its intensity/ severity and (3) focus on the impacts of past hazards in the same forests. For instance, thanks to dendrochronology and retrospective water balance modelling, we quantified the incidence of soil water deficits and other biotic events prior to the 2003 extreme event. Then, the extent to which past events interacted with the actual vulnerability of trees to extreme drought damage was taken into account (Beniston and Innes 1998). Indeed, we compared the response to recent hazard and to earlier drought events with similar intensity; we were able to demonstrate that the vulnerability to hazards increases with tree ageing.

\section{Dryade's outputs and deliverables}

To synthesize what was done, we adapted the core concepts described in the Special Report on Managing the Risks of Extreme Events and Disasters to Advance Climate Change Adaptation (SREX, IPCC 2012) to assess the risks of forest decline. The severity of adverse impacts of climate extremes (water deficit or excess) or biotic hazard depends on the severity of the extreme, on the exposure and on the vulnerability to the extreme (Fig. 1). We used here the SREX scheme to present the different papers collected in this special issue of Annals of Forest Sciences. Four components of vulnerability were investigated: (i) ecology-soil properties like extractable water, soil resistivity, topography and site fertility (Cailleret et al. 2014; Nourtier et al. 2014; Sergent et al. 2014b); (ii) tree ecophysiology-sap flux and its radial distribution as a function of changing water fluxes (Nourtier et al. 2014), carbon economy and radial distribution of carbohydrates in stems (Gérard and Bréda 2014); (iii) genetic diversity—among provenances (Sergent et al. 2014a) or species (Marçais and Desprez-Loustau 2014) and (iv) silviculture (DurandGillmann et al. 2014; Sergent et al. 2014b) - management, tree age and stand density. Main climatic events taken into account include periods of soil water deficit with their duration, intensity, date of occurrence and recurrence; this enabled us to assess the exposure of trees to water shortage taking into account local soil properties and stand properties (Nourtier et al. 2014; Sergent et al. 2014b). The risk components addressed in each paper from this special issue are indicated in Fig. 1.

Drought episodes during 2003-2006 were the driving factor of tree growth decrease, health decline and mortality for most of the species $\mathrm{x}$ regions studied cases. The repetition of drought episodes was more prejudicial than the absolute intensity and length of the 2003 extreme event itself. It induced a persistent growth decrease, a lack of recovery and even death of some individuals. Soil constraints to rooting, low water availability or low resistivity, delayed or inadequate thinning, tree age and sometimes nutrient availability were identified as the main vulnerability factors at stand level. At tree level, the vulnerability was related to species, provenance, and tree status and growth performance during juvenile growth or during years preceding 


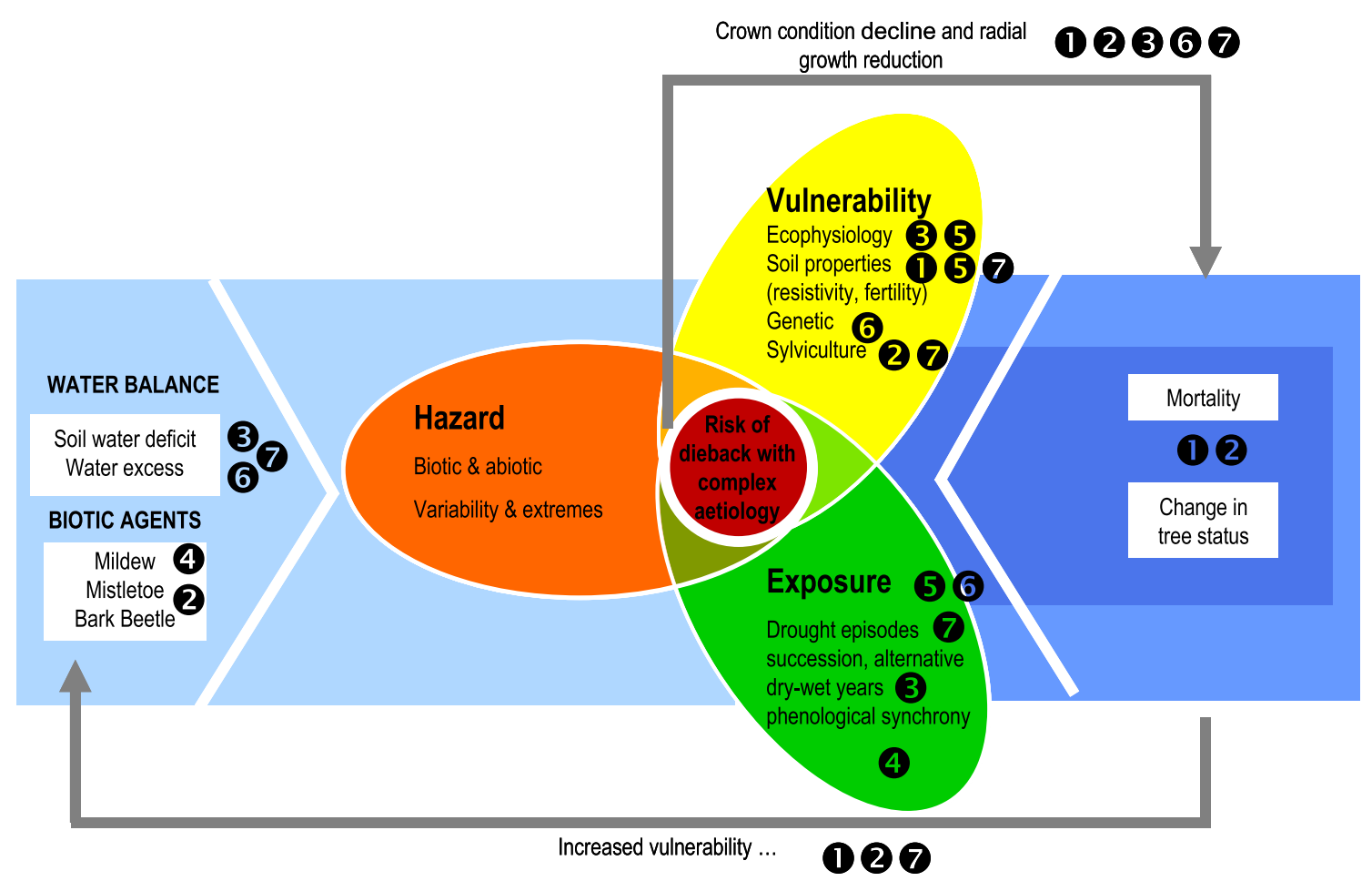

Fig. 1 Scheme of how exposure to climatic or biotic hazard of vulnerable forest stands and trees could result a risk of forest dieback, in most cases with a complex aetiology. Adapted from the core concepts of SREX report (IPCC 2012). Several components of vulnerability have been investigated in the Dryade project. Impacts on growth, health status and mortality were analysed to disentangle hazards, exposure and determinants of vulnerability. The papers gathered in this special issue are identified in the figure according to the main component(s) of risk addressed. (1) Cailleret et al. 2014, (2: Durand-Gillmann et al. 2014, (3: Gérard and Bréda 2014, (4: Marçais and Desprez-Loustau 2014, (5: Nourtier et al. 2014, (6: Sergent et al. 2014a, (0: Sergent et al. 2014b the extreme event. Individual vulnerability was assessed using sapwood width, radial growth and wood microdensity.

In the context of an increase of the occurrence of episodes of extreme water deficit, our findings suggest that the best performing trees were the most vulnerable to extreme drought events. Then, the following question was: which tradeoffs between growth performance and sustainability are the most appropriate to cope with extreme events? Taking into account the long term, because growth performance in the young age seemed to be an indicator of higher vulnerability at maturity, appeared essential in this reflection. Carbon allocation strategies among functions (growth, development reserves, fruiting) and among tree compartments (balance between aboveand below-ground biomass) were also prospected as functional causes of vulnerability. Should the decline be regarded as a selective force directed against the best performing trees (Guttschick and BassiriRad 2003)? If this was the case, the basics for a silviculture favouring the trees with the highest growth rate would be seriously challenged.

Our findings also confirmed the challenging need for progress in describing and recording dieback events of dieback. The networks of the national inventory and of forest health monitoring were invaluable for our research. Their maintenance in the long-term needs more than ever be guaranteed. But at the management level, the registration of phenomena is heterogeneous, partial and difficult to mobilize. We recommend formalizing this work through enhanced monitoring, memory of abnormal phenomena in support of future research work. This record should be regarded as an action towards adaptive management (Spittlehouse 2005). In a context of uncertainty about future climate and biotic disturbances, our results open up avenues to reduce the risk of dieback by management actions and selection of suitable tree species or provenances or silvicultural scheme, to both reduce the vulnerability of future stands and mitigate the intensity of water deficits. A variety of management options needs to be imagined right now in every situation recognized as vulnerable to improve the resilience of ecosystems and secure their long-term management (Bodin and Wiman 2007). To cope with adverse impacts of hazards especially in the most vulnerable situations, adaptive management by anticipation, consisting in forest renewal with species more drought resistant, seems preferable to reactive adaptation, namely crisis management of forest decline when they happen. 
Funding This work was funded by the ANR program Dryade (ANR-06-VULN-004). "Dryade: Vulnerability of forests to climate change: the tree bioclimatic areas" was a research project with a finalized vocation. It involved seven research units (UMR $1137 \mathrm{EEF}$, Nancy; UMR 1136 IAM, Nancy; UR 629 URFM, Avignon; UMR 1114 EMMAH, Avignon; UMR 1202 BIOGECO, Bordeaux; UR588 AGPF Orléans; EA LBLGC, Orléans), as well as the Institute for Forest Development (IDF), the National Forest Office (ONF), the National Forest Inventory (IFN, currently IGN) and the Department of Forest Health (DSF). The project started during January 2007 for 48 months.

\section{References}

Badeau V, Dupouey JL, Becker M, Picard JF (1995) Long-term growth trends of Fagus sylvatica L. in northeastern France. A comparison between high and low density stands. Acta Oecol 16:571-583

Badeau V, Becker M, Bert GD, Dupouey JL, Lebourgeois F, Picard JF (1996) Long-term growth trends of trees: ten years of dendrochronological studies in France. In: Spiecker H, Mielikäienen K, Köhl M, Skovsgaard JP (eds) Growth trends in european forests. Springer, Berlin, pp 167-181

Badeau V, Dupouey JL, Cluzeau C, Drapier J, Le Bas C (2010) Climate change and the biogeography of French tree species: first results and perspectives. In: Forest, Carbon Cycle and Climate Change, D. Loustau (Ed.), QUAE, ISBN 978-2-7592-0384-0, 231-252.

Becker M (1989) The role of climate on present and past vitality of silver fir forests in the Vosges Mountains of northeastern France. Can J Forest Res 19:1110-1117

Becker M, Bert GD, Bouchon J, Picard JF, Ulrich E (1994) Tendances à long terme observées dans la croissance de divers feuillus et résineux du Nord-est de la France depuis le milieu du XIX siècle. Rev For Fr XLVI:335-341

Belrose V, Nageleisen L-M, Renaud J-P (2004) Les conséquences de la canicule et de la sécheresse de 2003 : bilan à la fin de l'année 2003. http://agriculture.gouv.fr/IMG/pdf/25 canicule secheresse cle01e565.pdf. Accessed 17 July 2014

Belrose V, Pauly H, Nageleisen L-M, Bréda N (2006) Conséquences visibles de l'été 2003 sur les forêts : des réactions immédiates contrastées, des incertitudes sur les conséquences à long terme. RDV techniques $\mathrm{n}^{\circ} 11$ - hiver 2006 - ONF, 24-27. http://www.onf. fr/lire_voir_ecouter/++oid++925/@@display_media.html. Accessed 17 July 2014

Beniston M, Innes JL (1998) Impacts of climatic variability and extreme on forets: synthesis. The impacts of climate variability on forests. Lect Notes Earth Sci 74:309-318. doi:10.1007/BFb0009761

Bodin P, Wiman BLB (2007) The usefulness of stability concepts in forest management when coping with increasing climate uncertainties. Forest Ecol Manag 242:541-552. doi:10.1016/j.foreco. 2007.01.066

Bréda N (2013) Dryade - Comprendre la vulnérabilité des forêts aux aléas climatiques et biotiques. Environnement et Changements Globaux : des aléas à la vulnérabilité des sociétés - cahier ANR n7 - avril 2013, p 135. http://www.agence-nationale-recherche.fr/suivi-bilan/ consulter/environnement-et-changements-globaux-des-aleas-a-lavulnerabilite-des-societes-cahier-anr-n7-avril-2013. Accessed 17 July 2014

Briguglio L (2004) Economic vulnerability and resilience: concepts and measurements. In: Briguglio L, Kisanga EJ (eds) Economic vulnerability and resilience of small states. Islands and Small States Institute and London: Commonwealth Secretariat, Malta

Cailleret M, Nourtier M, Amm A, Durand-Gillmann M, Davi H (2014) Drought-induced decline and mortality of silver fir differ among three sites in Southern France. Ann For Sci (this issue). doi:10.1007/ s13595-013-0265-0

Carnicer J, Coll M, Ninyerola M, Pons X, Sánchez G, Peñuelas J (2011) Widespread crown condition decline, food web disruption, and amplified tree mortality with increased climate change-type drought. Proc Natl Acad Sci U S A 108:1474-1478. doi:10.1073/pnas. 1010070108

Cheaib A, Badeau V, Boe J, Chuine I, Delire C, Dufrêne E, François C, Gritti ES, Legay M, Pagé C, Thuiller W, Viovy N, Leadley P (2012) Climate change impacts on tree ranges: model intercomparison facilitates understanding and quantification of uncertainty. Ecol Lett 15:533-544. doi:10.1111/j.1461-0248.2012.01764.x

Dobbertin M (2005) Tree growth as indicator of tree vitality and of tree reaction to environmental stress: a review. Eur J Forest Res 124: 319-333. doi:10.1007/s10342-006-0110-1

Durand JL (2013) CLIMATOR L'impact du changement climatique sur les systèmes de culture et naturels représentatifs de la France. Environnement et Changements Globaux : des aléas à la vulnérabilité des sociétés - cahier ANR n ${ }^{\circ} 7$ - avril 2013, p 141. http://www.agence-nationale-recherche.fr/suivi-bilan/consulter/ environnement-et-changements-globaux-des-aleas-a-lavulnerabilite-des-societes-cahier-anr-n7-avril-2013. Accessed 17 July 2014

Durand-Gillmann M, Cailleret M, Boivin T, Nageleisen LM, Davi H (2014) Individual vulnerability of Silver fir (Abies alba Mill.) to parasitism by two contrasting biotic agents: mistletoe (Viscum album L. ssp. abietis) and bark beetles (Coleoptera: Curculionidae: Scolytinae) during a decline process. Ann For Sci (this issue). doi: 10.1007/s13595-012-0251-y

Eriksen SH, Kelly PM (2007) Developing credible vulnerability indicators for climate adaptation policy assessment. Mitig Adapt Strateg Glob Chang 12:495-524. doi:10.1007/s11027-006-3460-6

Fussel HM (2007) Vulnerability: a generally applicable conceptual framework for climate change research. Global Environ Chang 17: 155-167. doi:10.1016/j.gloenvcha.2006.05.002

Gérard B, Bréda N (2014) Radial distribution of carbohydrate reserves in the trunk of declining European beech trees (Fagus sylvatica L.) Ann For Sci (this issue). doi:10.1007/s13595-012-0240-1

Granier A (2013) FAST - La forêt française soumise au changement climatique et aux mutations de la filière bois. Environnement et Changements Globaux : des aléas à la vulnérabilité des sociétés cahier ANR n ${ }^{\circ} 7$ - avril 2013, p 136. http://www.agence-nationalerecherche.fr/suivi-bilan/consulter/environnement-et-changementsglobaux-des-aleas-a-la-vulnerabilite-des-societes-cahier-anr-n7avril-2013. Accessed 17 July 2014

Guttschick VP, BassiriRad H (2003) Extreme events as shaping physiology, ecology, and evolution of plants: toward a unified definition and evaluation of their consequences. New Phytol 160:21-42. doi: 10.1046/j.1469-8137.2003.00866.x

Holling CS (1986) The resilience of terrestrial ecosystems; local surprise and global change. In: Clark WC, Munn RE (eds) Sustainable development of the biosphere, vol. 10. Cambridge University Press, Cambridge, pp 292-317

Innes JL, Moffat AJ, Lonsdale D (1989) Weather conditions during the summer of 1989 and their effect on trees. Research information note 162, Farnham, Surrey Forestry Commission, Research Division 1989

IPCC (2012) Managing the risks of extreme events and disasters to advance climate change adaptation. In: Field CB, Barros V, Stocker TF, Qin D, Dokken DJ, Ebi KL, Mastrandrea MD, Mach KJ, Plattner G-K, Allen SK, Tignor M, Midgley PM (eds) A Special Report of Working Groups I and II of the Intergovernmental Panel on Climate Change. Cambridge University Press, Cambridge, p 582.

IPCC (2014) IPCC PCC WGII AR5, Glossary. Editor chairs: J. Agard and L. Schipper, p 30. http://ipcc-wg2.gov/AR5/images/uploads/ WGIIAR5-Glossary_FGD.pdf. Accessed 17 July 2014 
Jones EA, Reed DD, Mroz GD, Liechty HO, Cattelino PJ (1993) Climate stress as a precursor to forest decline - paper birch in Northern Michigan, 1985-1990. Can J Forest Res 23:229-233

Jurskis V (2005) Eucalypt decline in Australia, and a general concept of tree decline and dieback. Forest Ecol Manag 215:1-20. doi:10.1016/ j.foreco.2005.04.026

Landmann G (1994) Concepts, définitions et caractéristiques générales des dépérissements forestiers. Rev For Fr 5:405-415

Liang EY, Shao XM, Kong ZC, Lin JX (2003) The extreme drought in the 1920s and its effect on tree growth deduced from tree ring analysis: a case study in North China. Ann For Sci 60:145-152. doi:10.1051/ forest:2003007

Lloret F, Siscart D, Dalmases C (2004) Canopy recovery after drought dieback in holm-oak Mediterranean forest of Catalonia (NE Spain). Global Change Biol 10:2092-2099. doi:10.1111/j.1365-2486.2004.00870.x

Loustau D, Bosc A, Colin A, Davi H, François C, Dufrêne E, Déqué M, Cloppet E, Arrouays D, le Bas C (2005) Modelling the climate change effects on the potential production of French plains forests at the sub regional level. Tree Physiol 25:813-823

Manion PD (1991) Tree disease concepts. Prentice Hall, Englewood Cliffs

Manion PD (2003) Evolution of concepts in forest pathology. Phytopathology 93:1052-1055

Marçais B, Desprez-Loustau ML (2014) European oak powdery mildew: impact on trees, effects of environmental factors and potential effects of climate change. Ann For Sci (this issue). doi:10.1007/s13595012-0252-x

Nageleisen LM (2004) Recrudescence des insectes sous-corticaux à la suite des extrêmes climatiques de 2003. Bilan de la Santé des Forêts en 2003. Département de la Santé des forêts, p 5. http://agriculture.gouv.fr/IMG/ pdf/06_bilan_scolyte_2003_cle4b5b11.pdf. Accessed 17 July 2014

Nourtier M, Chanzy A, Cailleret M, Yingge X, Huc R, Davi H (2014) Transpiration of Silver Fir (Abies alba Mill.) during and after drought in relation to soil properties in a Mediterranean mountain area. Ann For Sci (this issue). doi:10.1007/s13595-012-0229-9

Pauly H, Belrose V (2005) Sécheresse et canicule 2003 : observations en 2004 des conséquences sur les peuplements forestiers adultes.
Département de la Santé des Forêts, Bilan de la Santé des forêts en 2004, Mai 2005, p 11 http://agriculture.gouv.fr/IMG/pdf/reseaux 2004_suite_secheresse_canicule.pdf. Accessed 17 July 2014

Piou D, Nageleisen LM, Desprez-Loustau ML, Candau JN (2006) Les risques sanitaires consécutifs à 2003 à la lumière de la littérature. RDV techniques $\mathrm{n}^{\circ} 11$ - hiver 2006 - ONF, 28-34. http://www.onf.fr/ lire_voir_ecouter/++oid++925/@@display_media.html. Accessed $17 \overline{\text { July }} \overline{2014}$

Rambal S (2013) Les écosystèmes forestiers méditerranéens face aux changements climatiques. Environnement et Changements Globaux: des aléas à la vulnérabilité des sociétés - cahier ANR $\mathrm{n}^{\circ} 7$ - avril 2013, p 135. http://www.agence-nationale-recherche.fr/ suivi-bilan/consulter/environnement-et-changements-globaux-desaleas-a-la-vulnerabilite-des-societes-cahier-anr-n7-avril-2013. Accessed 17 July 2014

Rouault G, Candau J-N, Lieutier F, Nageleisen L-M, Martin J-C, Warzée $\mathrm{N}$ (2006) Effects of drought and heat on forest insect populations in relation to the 2003 drought in Western Europe. Ann For Sci 63: 613-624. doi:10.1051/forest:2006044

Sergent AS, Bréda N, Sanchez L, Bastien JC, Rozenberg P (2014a) Coastal and interior Douglas-fir provenances differ in growth performance and response to drought episodes at adult age. Ann For Sci (this issue). doi:10.1007/s13595-014-0393-1

Sergent AS, Rozenberg P, Bréda N (2014b) Douglas-fir is vulnerable to exceptional and recurrent drought episodes and recovers less well on less fertile sites. Ann For Sci (this issue). doi:10.1007/s13595-0120220-5

Spittlehouse DL (2005) Integrating climate change adaptation into forest management. Forest Chron 81:691-695. http://www.for.gov.bc.ca/ hre/pubs/pubs/1394.htm. Accessed 17 July 2014

Thomas FM, Blank R, Hartmann G (2002) Abiotic and biotic factors and their interactions as causes of oak decline in Central Europe. For Path 32:277-307. doi:10.1046/j.1439-0329.2002.00291.x

Williams SE, Shoo LP, Isaac JL, Hoffmann AA, Langham G (2008) Towards and integrated framework for assessing the vulnerability of species to climate change. Plos Biol 6:2621-2626. doi:10.1371/ journal.pbio.0060325 